DOI: http://dx.doi.org/10.4314/star.v4i2.19 ISSN: 2226-7522(Print) and 2305-3372 (Online) Science, Technology and Arts Research Journal Sci. Technol. Arts Res. J., April-June 2015, 4(2): 157-163 Journal Homepage: http://www.starjournal.org/

Original Research

\title{
Early Mortality among HIV-positive Children Initiated Anti-retroviral Therapy in Eastern Ethiopia: A Retrospective Cohort Study
}

\author{
Dumessa Edessa $^{1^{*}}$, Fekede Asefa $^{2}$, and Jemal sheikahmed ${ }^{1}$ \\ ${ }^{1}$ School of Pharmacy, College of Health and Medical Sciences, Haramaya University, \\ Post Box: 235, Harar, Ethiopia \\ ${ }^{2}$ Department of Public Health, College of Health and Medical Sciences, Haramaya University, \\ Post Box: 235, Harar, Ethiopia
}

\begin{tabular}{|c|c|}
\hline Sin & Article Infor \\
\hline \multirow{14}{*}{ 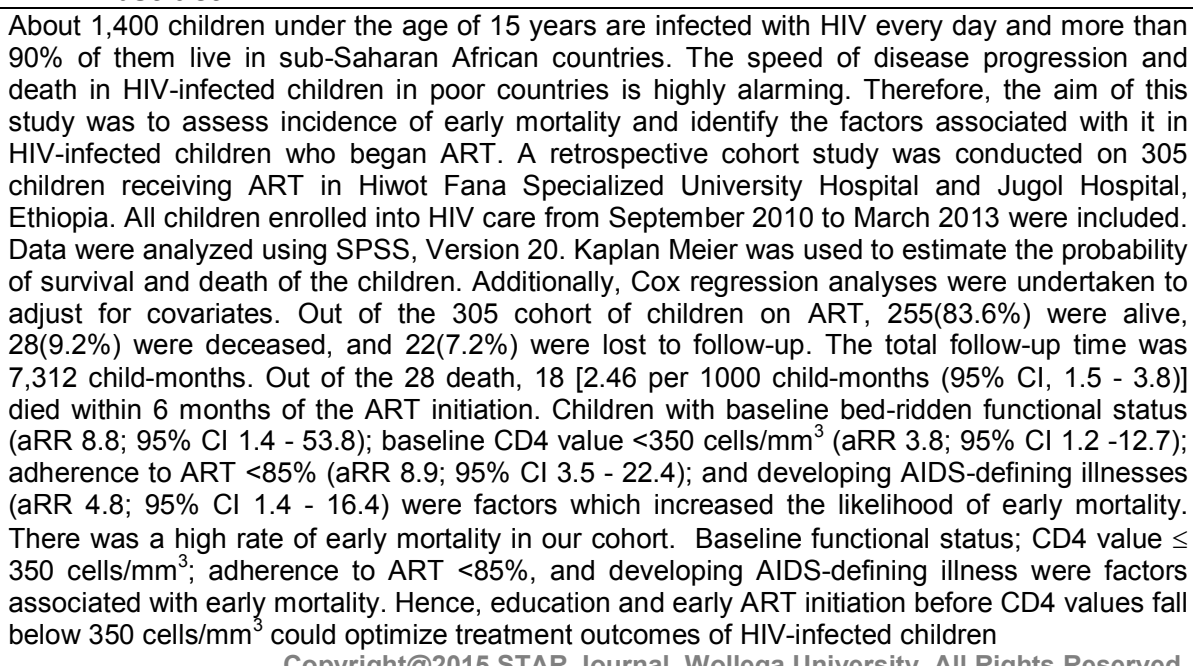 } & History: \\
\hline & Received : 27-03-2015 \\
\hline & : 03-06-2015 \\
\hline & Accepted : 15-06-2015 \\
\hline & Keywords: \\
\hline & Children \\
\hline & ART \\
\hline & Early mortality \\
\hline & Associated factors \\
\hline & \\
\hline & spondin \\
\hline & ssa Edessa \\
\hline & \\
\hline & \\
\hline
\end{tabular}

\section{INTRODUCTION}

The Human Immunodeficiency Virus (HIV) epidemic has brought a huge challenge to the survival of mankind (UNAIDS, 2009). According to the World Health Organization (WHO), there were approximately 35 million people worldwide living with HIVIAIDS in 2013. Of these, 3.2 million were children (<15 years old) (WHO/UNAIDS 2014). Sub-Saharan African countries remain most severely affected, accounting for $69 \%$ of the people living with HIV (PLHIV) worldwide (WHO, 2012). About 1,400 children under the age of 15 years are infected with HIV every day and more than $90 \%$ of the children who are HIV-positive live in sub-Saharan African countries (WHO/UNAIDS/UNICEF, 2011; WHO, 2012). The speed of disease progression and death among HIV-infected children in poor countries is alarming (Taha T. Graham et al., 2000). In addition, the questions of durability of the treatment response and its long-term effect on mortality have remained unanswered (Renaud-Théry et al., 2007). Consequently, in resource limited settings, there is a pressing need for research to further refine HIV treatment strategies among the children (Zanoni, Phungula et al.,
2011). In Ethiopia, there are very few research reports on the factors associated with early mortality among children who follow ART. This study, therefore, tries to explore the extent of early mortality and the clinical factors associated with the early mortality among the children on ART.

\section{MATERIALS AND METHODS}

\section{Study Area and Period}

The study was done in the ART clinics of Hiwot Fana Specialized University Hospital (HFSUH) and Jugol Hospital (JH), Harar, Eastern Ethiopia. Harar, the capital city of Harari Regional State, is about $526 \mathrm{Km}$ from Addis Ababa. In the town, there are two government hospitals (HFSUH and JH); one federal police hospital; one Army hospital; two private general hospitals; one Fistula hospital; eight government health centers; and nineteen health posts that provide health care services. The total health service coverage of the region is about $100 \%$. The study was done in June, 2014. 


\section{Study Design and Study Population}

A retrospective cohort study was employed on all the children ( $\mathrm{N}=305)$ enrolled into the chronic HIV care follow up from September 11, 2010 to March 31, 2013 at Hiwot Fana Specialized University Hospital and Jugol Hospital. Participants were HIV-positive children ( $\leq 15$ years).

\section{Data Collection and Quality Control}

To obtain complete data, the medical records of the study subjects were abstracted using a customized data collection form, which was pre-tested on $16(5 \%)$ study participants' medical records. The data abstractors were trained. Every day, after data collection, each datum was reviewed and checked for completeness by the supervisor and the principal investigator, and the necessary feedback was given to the data collectors the next day.

A study subjects' follow-up time would end either at his/her last visit to the HIV clinic or on March 31, 2014, the administrative censoring day. For a child who died or lost to follow-up during the follow-up period, the day he or she last visited the clinic was considered, as we could not know the exact day of the event.

\section{Study Variables}

Independent Variables: In this study, the independent variables were age, sex, weight, date of HIV diagnosis, previous history of TB or other opportunistic illnesses (Ols), WHO clinical stages, new diagnoses of WHO stage III/IV or persisting stage IV, AIDS-defining illnesses and adverse drug events (ADEs), rate of adherence to the therapy during the follow-up, results of diagnostic tests (including CD4 cell counts), Liver Function Tests (LFTs), Blood Urea Nitrogen (BUN), and Creatinine ( $\mathrm{Cr}$ ) level.

Dependent Variable: In this study, the outcome variable was death. The time to death was also considered as an endpoint.

\section{Data Processing and Analysis}

The data were entered into EpiData software and analyzed with SPSS Version 20.0. The baseline demographic and clinical characteristics of the study subjects were summarized using descriptive statistics: frequency, percent, and measures of central tendency and of dispersion. In addition, chi-squared $\left(\mathrm{X}^{2}\right)$ tests were used to identify the covariates of early mortality. The covariate for which the $p$-value was less than 0.20 by the bivariate analysis was retained for the subsequent multivariate analysis. The survival probability and the time to death of the study participants were determined by Kaplan Meier. Moreover, Cox regression analyses were used for adjusting covariates. In all of the analyses, levels of significance were determined via two-sided p-values $(\mathrm{P})$ and $95 \%$ confidence intervals $(95 \% \mathrm{Cl})$.

\section{Ethical Consideration}

The study was approved by the School of Pharmacy of Haramaya University, and to use the data from the clinical records, we obtained permission of the hospital's administration.

\section{RESULTS}

\section{Baseline Characteristics of the Cohort}

Data were retrospectively collected from the medical records of 305 cohorts of HIV-positive children aged $\leq 15$ years. More than half of the children were female $(52 \%)$. At ART initiation, of all study participants, $44.6 \%$ of them were $0-5$ years of age, the functional status of $52.5 \%$ of them was ambulatory, and $56.4 \%$ of them had CD4 values $<350$ cells $/ \mathrm{mm}^{3}$. About $15 \%$ of the children had history of documented tuberculosis and $49.3 \%$ of them were underweight at ART initiation. The mean haemoglobin of the cohort was $10.96 \mathrm{~g} / \mathrm{dl}(\mathrm{SD} \pm 1.98)$ at initiation of ART. More than half of the children (53\%) had anaemia, which was mild or moderate to severe (Table 1).

Table 1: Baseline socio-demographic and clinical characteristics of children on ART at HFSUH and JH, Sep 2010 - March 2013, Harar, Eastern Ethiopia

\begin{tabular}{|c|c|c|c|}
\hline Variable & Characteristics & Frequency & $\begin{array}{c}\begin{array}{c}\text { Percent } \\
(\%)\end{array} \\
\end{array}$ \\
\hline \multirow{3}{*}{ Sex } & Male & 146 & 47.9 \\
\hline & Female & 159 & 52.1 \\
\hline & $0-5$ years & 136 & 44.6 \\
\hline \multirow[t]{2}{*}{ Age } & $6-12$ years & 148 & 48.5 \\
\hline & $13-15$ years & 21 & 6.9 \\
\hline \multirow{3}{*}{$\begin{array}{l}\text { Educational } \\
\text { status }\end{array}$} & Under age & 179 & 58.7 \\
\hline & Primary & 98 & 32.1 \\
\hline & Secondary & 28 & 9.2 \\
\hline \multirow{4}{*}{$\begin{array}{l}\text { Baseline health } \\
\text { condition }\end{array}$} & Working & 134 & 43.9 \\
\hline & Ambulatory & 160 & 52.5 \\
\hline & Bed-ridden & 11 & 3.6 \\
\hline & $<350$ cells $/ \mathrm{mm}^{3}$ & 172 & 56.4 \\
\hline \multirow[t]{3}{*}{ CD4 cell count } & $\begin{array}{l}350-500 \\
\text { cells } / \mathrm{mm}^{3}\end{array}$ & 35 & 11.5 \\
\hline & $>500$ cells $/ \mathrm{mm}^{3}$ & 98 & 32.1 \\
\hline & Stage I & 52 & 17 \\
\hline Clinical WHO & Stage II & 115 & 37.7 \\
\hline \multirow[t]{2}{*}{ Stage } & Stage III & 118 & 38.7 \\
\hline & Stage IV & 20 & 6.6 \\
\hline \multirow{3}{*}{$\begin{array}{l}\text { Previous TB } \\
\text { history at } \\
\text { baseline } \\
\text { Documented } \\
\text { other }\end{array}$} & No & 259 & 85 \\
\hline & Yes & 46 & 15 \\
\hline & No & 43 & 14.4 \\
\hline $\begin{array}{l}\text { Ols history at } \\
\text { baseline }\end{array}$ & Yes & 262 & 85.6 \\
\hline \multirow{4}{*}{$\begin{array}{l}\text { Developmental } \\
\text { cornerstone }\end{array}$} & Appropriate & 76 & 24.9 \\
\hline & Delayed & 217 & 71.7 \\
\hline & Regression & 12 & 3.9 \\
\hline & Normal & 131 & 43.0 \\
\hline \multirow{4}{*}{$\begin{array}{l}\text { Nutritional status } \\
\text { at baseline }\end{array}$} & Underweight & 149 & 48.9 \\
\hline & Stunted & 18 & 5.9 \\
\hline & Wasted & 5 & 1.6 \\
\hline & Kwashiorkor & 2 & 0.7 \\
\hline \multirow{3}{*}{$\begin{array}{l}\text { Baseline anemia } \\
\text { status }\end{array}$} & No anemia & 143 & 47 \\
\hline & Mild anemia & 55 & 18 \\
\hline & $\begin{array}{l}\text { Moderate to } \\
\text { severe anemia }\end{array}$ & 107 & 35 \\
\hline
\end{tabular}

During the follow-up period, of all the study participants, $80.9 \%$ adhered to ART more than $95 \%$, $9.2 \%$ were died, and $44.3 \%$ and $28.9 \%$ developed new AIDS-defining illnesses and new WHO stage III/IV or persisting stage IV, respectively (Table 2 ). Eighteen of the 28 deceased cases occurred within 6 months of the ART initiation.

Table 3 shows that $56.4 \%$ of female participants had CD4 $\leq 350$ cells $/ \mathrm{mm}^{3}$ at ART initiation. About two-thirds of the participants $(65.7 \%)$ aged 6 to 15 years had CD4 $350 \mathrm{cells} / \mathrm{mm}^{3}$. Compared to their counterparts, of all the participants who had a CD4 $<350$ cells/ $\mathrm{mm}^{3}$ at ART initiation, $11 \%$ were in the WHO clinical stage IV, $18.6 \%$ had previous history of TB, $91.9 \%$ had previous history of other Ols, $79 \%$ were in regressed developmental status, $9.3 \%$ were stunted, $9.9 \%$ adhered to ART less than $85 \%$, and $50.6 \%$ had one or more new AIDS-defining illness diagnosis. 
Table 2: Cohort characteristics during follow-up period at HFSUH and JH, Sep 2010 - March 2013, Harar, Ethiopia

\begin{tabular}{lccc}
\hline \multicolumn{1}{c}{ Variable } & Characteristics & Frequency & Percent (\%) \\
\hline & $>95 \%$ adherence & 243 & 80.9 \\
& $85-95 \%$ adherence & 18 & 5.1 \\
Adherence to ART & $<85 \%$ adherence & 22 & 7.2 \\
& Lost to follow-up & 22 & 7.2 \\
& Alive & 255 & 83.6 \\
& Diseased & 28 & 9.2 \\
\hline \multirow{2}{*}{ Mortality within 6 months } & No & 265 & 93.7 \\
\hline \multirow{2}{*}{ TB diagnosed in the follow-up } & Yes & 18 & 6.3 \\
\hline \multirow{2}{*}{ New stage III/IV or persisting stage IV } & No & 266 & 87.9 \\
\hline & Yes & 39 & 12.1 \\
Documented adverse event in the follow-up & No & 217 & 71.1 \\
& Yes & 88 & 28.9 \\
\hline & No & 235 & 77 \\
Any AIDS-defining illness in the follow-up & Yes & 70 & 23 \\
\hline
\end{tabular}

Table 3: Characteristics of patients exposed to baseline lower or higher CD4 values at HFSUH and JH, September 2010 - March 2013, Harar, Ethiopia

\begin{tabular}{|c|c|c|}
\hline Characteristics & $\begin{array}{c}\text { CD4 } \leq 350 \\
\text { cells } / \mathrm{mm}^{3}-\text { No }(\%)\end{array}$ & $\begin{array}{c}\text { CD4 > } 350 \\
\text { cells/ } \mathrm{mm}^{3}-\text { No }(\%)\end{array}$ \\
\hline \multicolumn{3}{|c|}{ 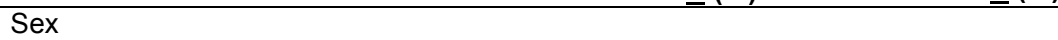 } \\
\hline Male & $75(43.6)$ & $71(53.4)$ \\
\hline Female & $97(56.4)$ & $62(46.6)$ \\
\hline \multicolumn{3}{|l|}{ Age (Years) } \\
\hline $0-5$ years & $59(34.3)$ & 77 (57.9) \\
\hline $6-15$ years & $113(65.7)$ & $56(42.1)$ \\
\hline \multicolumn{3}{|l|}{ Educational level } \\
\hline Under age for education & $87(50.6)$ & $92(69.2)$ \\
\hline Primary education & $66(38.4)$ & $32(24.1)$ \\
\hline Secondary education & $19(11)$ & $9(6.8)$ \\
\hline \multicolumn{3}{|l|}{ Health Condition } \\
\hline Working & $71(41.3)$ & $63(47.4)$ \\
\hline Ambulatory & $94(54.7)$ & $66(49.6)$ \\
\hline Bed-ridden & $7(4.1)$ & $4(3)$ \\
\hline \multicolumn{3}{|l|}{ WHO clinical stage } \\
\hline Stage I & $17(9.9)$ & $35(26.3)$ \\
\hline Stage II & $62(36)$ & $53(39.8)$ \\
\hline Stage III & $74(43)$ & $44(33.1)$ \\
\hline Stage IV & $19(11)$ & $1(0.8)$ \\
\hline \multicolumn{3}{|l|}{ Previous history of TB } \\
\hline No & $140(81.4)$ & $119(89.5)$ \\
\hline Yes & $32(18.6)$ & $14(10.5)$ \\
\hline \multicolumn{3}{|l|}{ Previous history of other Ols } \\
\hline No & $14(8.1)$ & $29(21.8)$ \\
\hline Yes & $158(91.9)$ & $104(78.2)$ \\
\hline \multicolumn{3}{|l|}{ Developmental Cornerstone } \\
\hline Appropriate & $28(16.3)$ & $48(36.1)$ \\
\hline Regression & $136(79)$ & $81(60.9)$ \\
\hline Delayed & $8(4.7)$ & $4(3)$ \\
\hline \multicolumn{3}{|l|}{ Nutritional status } \\
\hline Normal & $64(37.2)$ & $67(50.4)$ \\
\hline Underweight & $87(50.6)$ & $62(46.6)$ \\
\hline Stunted & $16(9.3)$ & $2(1.5)$ \\
\hline Wasted & $3(1.7)$ & $2(1.5)$ \\
\hline Kwashiorkor & $2(1.2)$ & $0(0)$ \\
\hline \multicolumn{3}{|l|}{ Adherence Status } \\
\hline$>95 \%$ & $127(73.8)$ & $116(87.2)$ \\
\hline $85-95 \%$ & $16(9.3)$ & $2(1.5)$ \\
\hline$<85 \%$ & $17(9.9)$ & $5(3.8)$ \\
\hline Lost to follow-up & $12(7)$ & $10(7.5)$ \\
\hline \multicolumn{3}{|l|}{ Anemia status } \\
\hline No anemia & $78(45.3)$ & $65(48.9)$ \\
\hline Mild anemia & $28(16.3)$ & $27(20.3)$ \\
\hline Moderate-severe anemia & $66(38.4)$ & 41 (30.9) \\
\hline \multicolumn{3}{|c|}{ New AIDS-defining illness diagnosis } \\
\hline No & $85(49.4)$ & $84(63.6)$ \\
\hline Yes & $87(50.6)$ & $48(36.4)$ \\
\hline
\end{tabular}




\section{Dumessa Edessa et alo,}

\section{Survival Pattern of the Cohort}

Out of the 305 cohort of children on ART, 255(83.6\%) were alive, $28(9.2 \%)$ died, and $22(7.2 \%)$ were lost to follow-up. After initiation of ART, the median time of survival the cohort was 30 months [Interquartile ranges (IQR) 18 - 30 months]. The cohort contributed to a total of 7,312 person-months (609 child-years) of follow up. For all the death cases, the median time of death was 4 months (IQR 0.9 - 7 months). The mortality rate of the cohort was 3.8 per 1000 child-months $(95 \%$ Cl, 2.6 - 5.4). Out of the 28 mortality cases, 18 [2.46 per 1000 childmonths $(95 \% \mathrm{Cl}, 1.5-3.8)$ ] died within 6 months of the
Sci. Technol. Arts Res. J., April-June 2015, 4(2): 157-163

ART initiation. Tuberculosis infections and other opportunistic infections were the causes of $32 \%$ and $25 \%$ of the deaths, respectively; whereas the causes of the remaining deaths were not recorded. The cumulative survival probabilities of the cohort were 0.91 at six months, 0.88 at twelve months, and 0.86 at twenty four months (Figure 1). However, children with CD4 > 350 cells $/ \mathrm{mm}^{3}$ at ART initiation had higher probability of survival compared to that of the children with CD4 $\leq 350$ cells $/ \mathrm{mm}^{3}$ (Figure 2).

\section{Survival Function}

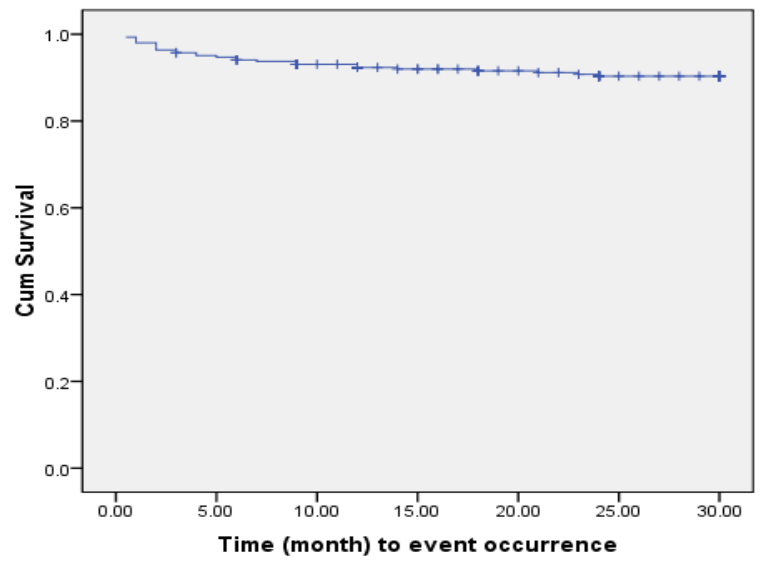

$\rightarrow$ Survival Function
+ Censored

Figure 1: Kaplan Meier survival curve among HIV -infected children on ART at HFSUH and JH, September 2010 March 2013

Survival Functions

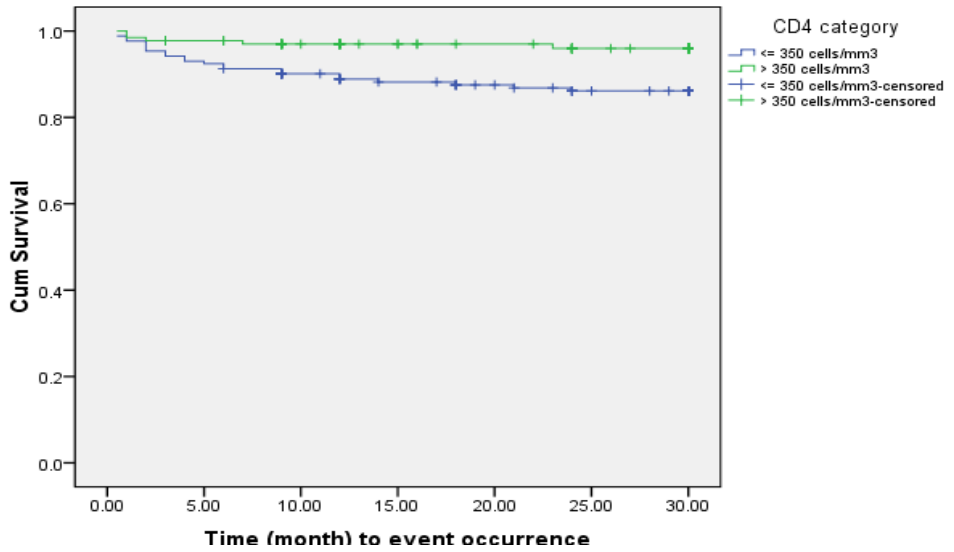

Figure 2: Kaplan Meier survival curve among HIV -infected children on ART with CD4 values $>350$ cells $/ \mathrm{mm}^{3}$ versus CD4 values $\leq 350$ cells $/ \mathrm{mm}^{3}$ at HFSUH and JH, September $2010-$ March 2013

\section{Factors Associated with Early Mortality}

In the bivariate analyses, the factors associated with increased likelihood of early mortality were baseline bedridden functional status, CD4 $\leq 350$ cells $/ \mathrm{mm}^{3}$, WHO stage IV, less than $95 \%$ adherence to ART, being under age for education, and developing AIDS-defining illness. The bed-ridden study subjects at the treatment initiation were 13.3 times more likely to die early than those who were working (cRR 13.3; 95\% Cl $4.7-37.7$ ). The children whose baseline CD4 was $\leq 350$ cells $/ \mathrm{mm}^{3}$ were 3.6 times more likely to die early compared to the children whose CD4 count was > 350 cells $/ \mathrm{mm}^{3}$ (cRR 3.6; $95 \% \mathrm{Cl}$
$1.4-9.5)$. Similarly, the children who adhered to ART < $85 \%$ were 8.4 times more likely to die early than the subjects who did so > 95\% (Table 4).

In the multivariate analyses, however, the factors associated with the early mortality were bed-ridden health status at ART initiation (adjusted risk ratio [aRR] 8.8; 95\% Cl $1.4-53.8)$, CD4 values $\leq 350$ cells $/ \mathrm{mm}^{3}$ at ART initiation (aRR 3.86; 95\% Cl $1.17-12.7$ ), <85\% adherence to ART (aRR 8.9;95\% Cl 3.52-22.4), and developing AIDS-defining illness in the follow-up (aRR 4.8; 95\% Cl 1.4- 16.4). 
Table 4: Factors associated with early mortality among HIV-infected children initiated with ART, Harar, Eastern Ethiopia, September 2010-March 2013

\begin{tabular}{|c|c|c|}
\hline Factor & CRR (95\% Cl) & aRR $(95 \% \mathrm{Cl})$ \\
\hline \multicolumn{3}{|l|}{ Sex } \\
\hline Male & 1 & 1 \\
\hline Female & $1.24(0.48-3.22)$ & $1.4(0.56-3.58)$ \\
\hline \multicolumn{3}{|l|}{ Age } \\
\hline$\leq 5$ years & 1 & 1 \\
\hline $6-15$ years & $1.03(0.81-1.31)$ & $0.7(0.19-2.54)$ \\
\hline \multicolumn{3}{|l|}{ Health Condition } \\
\hline Working & 1 & 1 \\
\hline Ambulatory & $0.92(0.31-2.72)$ & $1.24(0.47-3.30)$ \\
\hline Bed-ridden & $13.3(4.7-37.7)^{\star}$ & $8.8(1.4-53.8)^{*}$ \\
\hline \multicolumn{3}{|l|}{ Baseline CD4 cell counts } \\
\hline$\leq 350$ cells $/ \mathrm{mm} 3$ & $3.6(1.4-9.5)$ & $3.86(1.17-12.7)^{\star}$ \\
\hline$>350$ cells $/ \mathrm{mm} 3$ & 1 & 1 \\
\hline \multicolumn{3}{|l|}{ WHO clinical stage } \\
\hline Stage I & 1 & 1 \\
\hline Stage II & $0.15(0.04-0.62)$ & $0.17(0.03-1.05)$ \\
\hline Stage III & $0.15(0.05-0.46)$ & $0.17(0.03-0.94)$ \\
\hline Stage IV & $0.27(0.12-0.71)^{\star}$ & $0.40(0.04-3.85)$ \\
\hline \multicolumn{3}{|l|}{ Previous history of TB } \\
\hline No & 1 & 1 \\
\hline Yes & $2.23(0.74-6.70)$ & $1.34(0.45-4.04)$ \\
\hline \multicolumn{3}{|l|}{ History of Ols other than TB } \\
\hline No & 1 & 1 \\
\hline Yes & $3.25(0.42-25.29)$ & $3.2(0.26-38.5)$ \\
\hline \multicolumn{3}{|l|}{ Adherence to ART } \\
\hline$>95 \%$ & 1 & 1 \\
\hline $85-95 \%$ & $3.86(1.07-13.8)^{*}$ & $1.6(0.35-7.2)$ \\
\hline$<85 \%$ & $8.4(3.8-18.5)^{*}$ & $8.9(3.52-22.4)^{\star}$ \\
\hline \multicolumn{3}{|l|}{ Educational status } \\
\hline Under age & 1 & 1 \\
\hline Primary or Secondary & $0.36(0.15-0.89)^{*}$ & $0.40(0.14-1.13)$ \\
\hline \multicolumn{3}{|l|}{ AIDS-defining illness } \\
\hline No & 1 & 1 \\
\hline Yes & $7.8(2.7-22.6)^{*}$ & $4.8(1.4-16.4)^{\star}$ \\
\hline
\end{tabular}

\section{DISCUSSION}

The finding of this study indicated that there were 28 deaths in 609 child-years of follow up, providing an incidence density of 46 deaths per 1000 child-years. Many of the deaths (18) occurred early, within the first 6 months of the ART initiation. The rate of early mortality was 2.46 deaths per 1000 child-months, whereas that of the overall was 3.83 deaths per 1000 child-months. The factors associated with the early mortality were baseline bedridden functional status, baseline CD4 values $\leq 350$ cells $/ \mathrm{mm}^{3}$; less than $85 \%$ adherence to ART, and developing AIDS-defining illness during follow up.

The overall mortality rate found in this study (46 deaths per 1000 child-years; 3.83 deaths per 1000 childmonths) is almost similar to the rate reported from a study in Kenya (47 deaths per 1000 child-years) (Wamalwa DC, Farquhar C et al., 2007), but it is higher than the ones from Central Ethiopia (2.06 deaths per 100 child-years), and from Northern Ethiopia (16.85 deaths per 1000 child-years) (Gebremedhin et al., 2013; Kedir et al., 2014). Moreover, in our study, the early death rate was nearly as high as the rates found by similar studies done in Ethiopia (Koye Ayele et al., 2012; Gebremedhin et al., 2013; Kedir et al., 2014) and sub-Saharan African countries (Moore et al., 2011; Steele et al., 2011; Zanoni et al., 2011; Carolyn et al., 2007). At baseline, $15 \%$ of the children had TB history, and like in other studies (Moore et al., 2011; Zanoni et al., 2011), it was a major (32\%) contributing factor for the death. From the usual clinical experience, there was a delayed presentation for HIV diagnosis and treatment, as well.

The early mortality was significantly associated with the CD4 values of the study subjects. Like studies done on different cohorts of ART receiving participants (Puthanakit et al., 2007; Zanoni et al., 2011; Gebremedhin et al., 2013; Kedir et al., 2014), in this study the children with baseline CD4 values $\leq 350$ cells $/ \mathrm{mm}^{3}$ were 3.86 times more likely to die early than the children with baseline CD4 values > 350 cells $/ \mathrm{mm}^{3}$. Recovery of immune status with ART in children has also been shown to be dependent on the baseline CD4 values at initiation of treatment (Newell et al., 2006; Patel et al., 2008). Initiation of ART in children with severe immune suppression is more likely to result in the development of immune reconstitution inflammatory syndrome (IRIS), which can be associated with potential mortality in the early months after initiation of ART (Puthanakit et al., 2007). There was also greater proportion of the children with documented history of TB and other Ols among patients with CD4 values $\leq 350$ cells $/ \mathrm{mm}^{3}$ that could contribute for early death compared to patients with CD4 values $>350$ cells $/ \mathrm{mm}^{3}$.

The early mortality was also significantly associated with the presence of AIDS-defining illness (Ols) during follow up. The children who developed AIDS-defining illness during the follow up period were 4.8 times risker to 
early mortality compared to their counter parts. This is consistent with other studies (Grinsztejn et al., 2009; Brady et al., 2010). About $45 \%$ of the children in our cohort started ART at advanced WHO clinical stage (III/IV), which could result in multi organ failure, progressive malnutrition due to lack of intake, increased metabolic rate, immune dysfunction, chronic infectious and non-infectious inflammatory complications (Brady, Oleske et al., 2010). Late presentation and starting ART with advanced symptomatic disease may lead even to death ( Janssen et al., 2010; Koye et al., 2012).

Furthermore, the early death was closely linked to the children's level of adherence to ART. The study subjects whose adherence to ART was $<85 \%$ were 8.9 times more likely to early mortality than those whose adherence to ART was $\geq 95 \%$. A study in rural Uganda also revealed an 8.8 times increased hazard of death among individuals with adherence to therapy < 95\% (Moore et al., 2011). In addition, a study in Botswana provides an evidence that suboptimal early ART adherence as measured by pharmacy refill data and pill counts increases the risk of early mortality(Steele et al., 2011). This could be due to low virologic suppression and subsequent AIDS progression in the setting of low levels of ART adherence.

At the initiation of the ART, although some of the study participants had moderate to severe anemia (35\%) and few had mild $(18 \%)$, unlike the reports from other studies (Janssen et al., 2010; Koye et al., 2012; Kedir et al., 2014; Carolyn Bolton-Moore et al., 2007), we found no association between the baseline anemia status and the early mortality. Similarly, more than half of the children were underweight (low weight-for-age). Several studies revealed that growth failure is a predictor of mortality (Wamalwa et al., 2007; Koye et al., 2012; Kedir et al., 2014). However, this nutritional problem was also not significantly associated with the early mortality in our study. The small number of our study subjects might have contributed to the inconsistencies between our finding and the others'.

Though long duration of follow-up was made for reliable outcome, there were some limitations to this study. Firstly, the data were abstracted from the medical records and may suffer from variable deficiencies that could result into under- or over-estimations of early mortality. Secondly, early mortality might be underestimated since lost to follow-up might also include those who died without being reported. Thirdly, nearly half of the deaths were without diagnosed clinical cause (s) and measurement of specific disease-caused mortality was not complete. Therefore, any interpretation of the findings in this study should consider these limitations.

\section{CONCLUSIONS}

The present cohort study demonstrated that the overall mortality rate was 3.83 deaths per 1000 child-months. In addition, more than two-thirds of the total deaths (2.46 deaths per 1000 child-months) occurred in the first sixth months ART initiation. Bed-ridden functional status at ART initiation, CD4 values $\leq 350$ cells $/ \mathrm{mm}^{3}$ at ART initiation, $<85 \%$ adherence to ART, and developing AIDSdefining illness were independently associated with early mortality. Hence, early initiation of ART before the fall of CD4 values < 350 cells $/ \mathrm{mm} 3$, and targeted interventions should be prepared to intensify support and care for children, especially during the first sixth months of ART initiation. Educating children or family on the importance of adherence to treatment could optimize the treatment outcome of HIV-positive.

\section{Acknowledgments}

The authors would like to acknowledge Haramaya University, School of Pharmacy for reviewing and making approval of the study. Our special thanks also go to the administration and the workers in HFSUH and $\mathrm{JH}$ for their cooperation.

\section{Conflict of Interest}

The authors would like to declare that there is no conflict of interest.

\section{REFERENCES}

Brady, M.T., Oleske, J.M., Williams, P.L., Elgie, C. Mofenson, L.M., Dankner, W.M., Van Dyke, R.B. (2010). Declines in Mortality Rates and Changes in Causes of Death in HIV-1-Infected Children during the HAART Era. Journal of Acquired Immune Deficiency Syndrome 53(1): 86-94.

Bolton-Moore, C., Mubiana-Mbewe, M., Cantrell, R.A., Chintu, N., Stringer, E.M., Chi, B.H., Sinkala, M. Kankasa, C., Wilson, C.M., Wilfert, C.M., Mwango, A., Levy, J., Abrams, E.J., Bulterys, M., Stringer, J.S. ( 2007). Clinical Outcomes and CD4 Cell Response in Children Receiving Antiretroviral Therapy at Primary Health Care Facilities in Zambia. JAMA 298(16): 1888-1899.

Gebremedhin, A., Gebremariam, S., Haile, F., Weldearegawi, B., Decotelli, C. (2013). Predictors of mortality among HIV infected children on anti-retroviral therapy in Mekelle Hospital, Northern Ethiopia: a retrospective cohort study. BMC Public Health 13(1047): 1-6.

Grinsztejn, B., Veloso, V.G., Friedman, R.K., Moreira, R.I., Luz, P.M., Campos, D.P., Pilotto, J.H., Cardoso, S.W., Keruly, J.C., Moore, R.D. (2009). Early mortality and cause of deaths in patients using HAART in Brazil and the United States. AIDS 23: 2107-2114.

Janssen, N., Ndirangu, J., Newell, M.L., Bland, R.M. (2010) Successful paediatric HIV treatment in rural primary care in Africa. Archives of Disease in Childhood 95: 414-421.

Kedir, A.A., Alem Desta and Girmatsion Fesseha (2014). Factors Affecting Survival of HIV Positive Children Taking Antiretroviral Therapy at Adama Referral Hospital and Medical College, Ethiopia. Journal of AIDS \& Clinical Research 5(3): 1-6.

Koye, D. N., Tadesse Awoke Ayele and Berihun Megabiaw Zeleke (2012). Predictors of mortality among children on Antiretroviral Therapy at a referral hospital, Northwest Ethiopia: A retrospective follow up study. BMC Pediatrics 12(161).

Moore, D. M., Yiannoutsos, C.T., Musick, B.S., Tappero, J., Degerman, R., Campbell, J., Were, W., Kaharuza, F., Alexander, L.N., Downing, R., Mermin, J. (2011). Determinants of Early and Late Mortality among HIVInfected Individuals Receiving Home-Based Antiretroviral Therapy in Rural Uganda. Journal of Acquired Immune Deficiency Syndrome 58(3): 289-296.

Newell, M.L., Patel, D., Goetghebuer, T., Thorne, C. (2006). CD4 cell response to antiretroviral therapy in children with vertically acquired HIV infection: is it associated with age at initiation? Journal of Infectious Disease 193: 954-962.

Patel, K., Miguel A. Hernán., Paige L. Williams., John D. Seeger., Kenneth Mclntosh., Russell B. Van Dyke., 
Dumessa Edessa et al.,

George R. Seage III. (2008 ). Long-Term Effects of Highly Active Antiretroviral Therapy on CD4 Cell Evolution among Children and Adolescents Infected with HIV: 5 Years and Counting. Clinical Infectious Diseases 46: 1751-60.

Renaud-Théry, F., Nguimfack, B.D., Vitoria, M., Lee, E., Graaff, P., Samb. B., Perriëns, J. (2007). Use of antiretroviral therapy in resource-limited countries in 2006: distribution and uptake of first- and second-line regimens. AIDS 21(4): 89-95.

Steele, K.T., Steenhoff, A.P., Newcomb, C.W., Rantleru, T., Nthobatsang, R., Lesetedi, G., Bellamy, S.L., Nachega, J.B., Gross, R., Bisson, G.P. (2011). Early Mortality and AIDS Progression Despite High Initial Antiretroviral Thrapy Adherence and Virologic Suppression in Botswana.PLOS ONE 6(6).

Taha, T.E., Graham, S.M., Kumwenda, N.I., Broadhead, R.L., Hoover, D.R., Markakis, D., van Der Hoeven, L., Liomba, G.N., Chiphangwi, J.D., Miotti, P.G. (2000). Morbidity among human immunodeficiency virus-infected and uninfected African children. Pediatrics 106(77).

Thanyawee Puthanakit., Linda Aurpibul., Peninnah Oberdorfer., Noppadon Akarathum., Suparat Kanjananit., Pornphun Wannarit., Thira Sirisanthana and Virat Sirisanthana (2007). Hospitalization and Mortality among HIV-Infected Children after Receiving Highly Active
Sci. Technol. Arts Res. J., April-June 2015, 4(2): 157-163

Antiretroviral Therapy. Clinical Infectious Diseases 44(4): 599-604.

UNAIDS (2009). Report on the global AIDS epidemic. Geneva, Switzerland, UNAIDS.

Wamalwa, D.C., Farquhar, C., Elizabeth M. Obimbo, Sara Selig., Dorothy A. Mbori-Ngacha., Barbra A. Richardson., Julie Overbaugh., Sandy Emery., Grace Wariua., Christine Gichuhi., Rose Bosire, and Grace John-Stewart (2007). Early response to highly active antiretroviral therapy in HIV-1-infected Kenyan children. Journal of Acquired Immune Deficiency Syndrome 45(3): 311-317.

WHO (2012). Global report: UNAIDS report on the global AIDS epidemic 2012, UNAIDS.

WHO/UNAIDS (2014). HIVIAIDS Fact Sheet, WHO.

WHO/UNAIDS/UNICEF (2011). Towards universal access and Scaling up priority HIVIAIDS interventions in the health sector, Progress Report.

Zanoni, B.C., Phungula, T., Zanoni, H.M., France, H., Feeney, M.E. (2011). Risk Factors Associated with Increased Mortality among HIV Infected Children Initiating Antiretroviral Therapy (ART) in South Africa. PLoS ONE $6(7)$. 